\title{
Influence of Environmental Temperature and Electrolyte Balance on the Performance of Quails (Coturnix Coturnix Coturnix)
}

http://dx.doi.org/10.1590/1516-635x1603249-256

\section{-Author(s)}

\section{Barbosa Lima R'}

Silva JHV da"

Givisiez PEN'

Martins TDD"

Saraiva EPI

Costa FGPI

Macari M"I

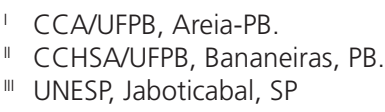

Corresponding author e-mail address: rodrigo_zoo@yahoo.com.br

\section{nKeywords}

Ammonium chloride, heat stress, sodium bicarbonate.

\section{ABSTRACT}

High environmental temperatures have a negative effect on the production efficiency of poultry reared in hot climates. This study evaluated the efficiency of electrolyte supplementation under high environmental temperature conditions by manipulating water and feed electrolyte balance (EB) on the survival and performance of European quails. In experiment 1, a completely randomized experimental design was applied in a $4 \times 2$ factorial arrangement. Treatments consisted in four feed EB values $(0,120,240,360 \mathrm{mEq} / \mathrm{kg}$ ), and two environmental temperatures ( 25 and $34^{\circ} \mathrm{C}$ ). Feed electrolyte balance was manipulated by the addition of sodium bicarbonate and ammonium chloride. In experiment 2, birds were randomly distributed according to a $5 \times 2$ factorial arrangement. Treatments consisted in five $\mathrm{BE}$ values in the drinking water $(0,30,60,90,120 \mathrm{mEq} / \mathrm{L})$ and two environmental temperatures $\left(25\right.$ and $34{ }^{\circ} \mathrm{C}$ ). Only sodium bicarbonate was added to the water to obtain the different $B E$ values. The experiments were carried out simultaneously in environmental chambers at constant temperatures with 20- to 37-d-old quails. Most evaluated parameters were influenced by temperature in both experiments. In experiment 1, EB affected water intake and intestinal length. In experiment 2, EB values influenced $(p<0.05)$ water intake and heart and liver relative weights. Electrolyte balance values of $120 \mathrm{mEq} / \mathrm{kg}$ of feed and of 30 $\mathrm{mEq} / \mathrm{L}$ of drinking water are recommended to increase water intake of grower European quails reared under hot temperature.

\section{INTRODUCTION}

High environmental temperature is the main cause of heat stress and may negatively affect poultry production in tropical regions, particularly when its interactions with radiation, relative humidity, and air velocity are considered. The production efficiency in these regions may be improved by reducing heat stress, by minimizing effective temperature, or by favoring heat loss. The supplementation of electrolytes in the drinking water or feed is well accepted by both researchers and farmers because it is convenient and cheap. The use of electrolytes, particularly saline solutions, prevents dehydration and promotes voluntary water intake in humans (Wilk et al., 2007), and have similar effects in poultry.

Electrolyte concentrations and the maintenance of acid-base balance in body fluids (Mongin, 1981) are studied under the term electrolyte balance (EB). The electrolyte balance varies as a function of diet and water balance, and it is particularly important in poultry under high temperatures due to panting. In addition, EB values in the diet change with animal species, production category, and age, as well as with the intensity and duration of heat stress. Experiments carried out with broilers, commercial layers, and broiler breeders determined different 
dietary EB for these categories of chickens (Junqueira et al., 2000, Borgatti et al., 2004) and for different environmental temperatures. Quails originate from hot regions (Mcllvaine, 2000), and therefore, probably are more resistant to heat stress than chickens.

There are few literature reports on the electrolyte balance of quails. Therefore, the results of experiments with broilers reared under high environmental temperatures using very narrow EB ranges may not be extrapolated to quails. Ross (1979) investigated sodium intake in two broilers strains and concluded that sodium is more efficiently utilized when added to the drinking water than to the feed. This indicates that not only the salts added, but also supplementation route may be relevant and influence the results. Such considerations have practical effects on quail production in hot climates and improve production efficiency. The objective of the present study was to evaluate the effect of electrolyte balance of the drinking water and of the feed in quails reared at 34 and $25^{\circ} \mathrm{C}$.

\section{MATERIALS AND METHODS}

Experiment 1: 240 male and female European quails were distributed at 20 days of age to the treatments according to a completely randomized experimental design in a $4 \times 2$ factorial arrangement. Treatments consisted of feeds with four electrolyte balance values $(0,120,240,360 \mathrm{mEg} / \mathrm{kg})$ and two environmental temperatures $\left(34\right.$ and $25^{\circ} \mathrm{C} \pm 2{ }^{\circ} \mathrm{C}$ ) with five replicates of six birds each.

The $\mathrm{BE}$ values were obtained by adding sodium bicarbonate $\left(\mathrm{NaHCO}_{3}\right)$ and/or ammonium chloride $\left(\mathrm{NH}_{4} \mathrm{Cl}\right)$ to the basal feed. Feed electrolyte balance $\left[\mathrm{Na}^{+}+\mathrm{K}^{+}-\mathrm{Cl}^{-}\right]$was calculated according to Mongin $(1981)$ as $\left[\left(\% \mathrm{Na}^{+} \times 104 / 23\right)+\left(\% \mathrm{~K}^{+} \times 104 / 39.1\right)-\% \mathrm{Cl}^{-}\right.$ $x$ 104/35.5)]. The highest and the lowest EB values were calculated to higher and lower than the upper and lower limit of the normal EB range expected in practical diets (Silva e Costa, 2009).

Experiment 2: 360 male and female European quails were distributed at 20 days of age to the treatments according to a completely randomized experimental design in a $5 \times 2$ factorial arrangement. Treatments consisted of drinking water with five electrolyte balance values $(0,30,60,90,120 \mathrm{mEq} / \mathrm{kg})$ and two environmental temperatures $\left(34\right.$ and $25^{\circ} \mathrm{C} \pm 2{ }^{\circ} \mathrm{C}$ ) with five replicates of six birds each. In both experiments, birds were individually weighed (initial weight of 126.2 $\pm 5.4 \mathrm{~g}$ ) before distribution into the experimental units in order to obtain uniform unit weight. Birds were fed a "null" EB value, in $\mathrm{mEq} / \mathrm{kg}$, by adding $1.18 \% \mathrm{NH}_{4} \mathrm{Cl}$ to the basal diet. The $\mathrm{NaHCO}_{3}$ supplementation doses in de-ionized drinking water were established after a pilot study that resulted in mortality of quails drinking water with $\mathrm{EB}$ values higher than $120 \mathrm{mEq}$ due to starvation. In order to obtain the EB values of 30,60 , 90 , and $120 \mathrm{meq} / \mathrm{L}$, sodium bicarbonate levels of 2.55 , $5.1,7.65$, and $10.2 \mathrm{~g}$ were added to the drinking water, respectively. Water was supplied in plastic drinkers $(300 \mathrm{~mL})$, which were refilled four times daily.

The diets contained $23 \%$ crude protein and 2900 $\mathrm{kcal}$ metabolizable energy/ $/ \mathrm{kg}$, according to the recommendations of Silva \& Costa (2009), as shown in Table 1.

Table 1 - Composition of the experimental feeds used in experiments 1 and 2 .

\begin{tabular}{lcccc}
\hline EB $(\mathrm{mEq} / \mathrm{kg})$ & ${ }^{(1)} \mathrm{Null}$ & 120 & 240 & 360 \\
\hline Ingredients & & & & \\
\hline Corn & 62.3 & 62.3 & 62.3 & 62.3 \\
\hline Soybean meal & 33.3 & 33.3 & 33.3 & 33.3 \\
\hline Dicalcium phosphate & 1.01 & 1.01 & 1.01 & 1.01 \\
\hline Limestone & 0.84 & 0.84 & 0.84 & 0.84 \\
\hline DL-methionine & 0.249 & 0.249 & 0.249 & 0.249 \\
\hline Salt & 0.177 & 0.177 & 0.177 & 0.177 \\
\hline Vitamin premix ${ }^{(3)}$ & 0.1 & 0.1 & 0.1 & 0.1 \\
\hline Mineral premix ${ }^{(5)}$ & 0.07 & 0.07 & 0.07 & 0.07 \\
\hline Choline chloride $^{(4)}$ & 0.09 & 0.09 & 0.09 & 0.09 \\
\hline L-threonine $^{(4)}$ & 0.122 & 0.122 & 0.122 & 0.122 \\
\hline L-Lysine HCL $^{(4)}$ & 0.112 & 0.112 & 0.112 & 0.112 \\
\hline BHT $^{(6)}$ & 0.01 & 0.01 & 0.01 & 0.01 \\
\hline NH $_{4} \mathrm{Cl}$ & 1.179 & 0.533 & 0 & 0 \\
\hline NaHCO $_{3}$ & 0.142 & 0.142 & 0.320 & 1.342 \\
\hline Inert material & 0.281 & 0.927 & 1.282 & 0.26 \\
\hline Total & 100 & 100 & 100 & 100 \\
\hline
\end{tabular}

(1) Feed with null EB used in experiment 2; (2) Vitamin premix (content $/ \mathrm{kg}$ ): Vit. A $12,000,000$ IU; Vit. D3 - 3,600,000 IU; vit. B1 - 2,500 mg; Vit,B2 - 8,000 $\mu \mathrm{g}$; Vit, B6 - 5,000 mg; pantothenic acid - 12,000 g; biotin - 200 mg; Vit, K3 - 3,000 mg; folic acid - 1,500 mg; nicotinic acid - 40000 mg; vit, B12 - 20,000 mcg; selenium - 150 mg; excipient, q.s.p. - 1000 g. (3) Chlorine content derived from lysine $\mathrm{HCl}$ and choline chloride were calculated. (4) Mineral premix (content $/ \mathrm{kg}$ ): manganese $160.0 \mathrm{~g}$; iron $100.0 \mathrm{~g}$; zinc - $100.0 \mathrm{~g}$; copper - $20.0 \mathrm{~g}$; cobalt - $2.0 \mathrm{~g}$; iodine $-2.0 \mathrm{~g}$; excipient q. s. p. -1000 g. (5) Antioxidant.

Birds were housed in vertical battery cages $(0.33$ $\times 0.5 \times 0.15 \mathrm{~m}$ each) placed in an environmentally controlled room with temperatures of $25^{\circ} \mathrm{C}$ or $34^{\circ} \mathrm{C}$. Birds were identified per experimental unit using color plastic rings.

Comfort temperature was controlled using an air conditioner (18000 BTU). The room was heated using 250-W incandescent lamps (Mega Spot IV22514, Empalux) placed one meter away from the battery and one meter from the floor. Thermal environment was monitored using maximum-minimum digital thermometers (INCONTERM) and a thermo-hygrometer, 
consisting of a dry and a wet bulb thermometer to control air relative humidity. Water temperature was measured using an infrared digital thermometer (MT360 , Minipa) in $20 \%$ of the experimental units. The temperatures measured by the thermometers were recorded daily at 08:00, 11:00, 14:00, and 17:00 hours.

Water intake and average feed intake were calculated per experimental unit, divided by the number of birds in the unit and by the number of experimental days. Average weight gain was calculated as the weight gain of the experimental unit divided by the number of birds in each unit. At the end of the experimental periods, birds were fasted for 12 $h$, weighed, and sacrificed. Carcass yield and organ relative weights were evaluated in two quails per experimental unit that represented the average weight of the unit. Carcass yield was calculated as the ratio between plucked carcass weight and body weight after fasting. Liver, gizzard, intestine, and heat relative weights were calculated relative to carcass weight.

Data complied with the assumptions of normality of studentized residuals (Shapiro-Wilk test) and variance homogeneity (Hartley test), and were submitted to analysis of variance. When results were significant, analysis of regression was applied considering the linear and quadratic fit of the data according to the best of the model for each parameter. The coefficient of determination, which indicates how well the obtained means are fit to the model.

Interactions were deployed even when they were not significant by the $\mathrm{F}$ test, but the parameters were significantly affected by both evaluated factors. According to Sampaio (1998), when the degree of freedom is higher than 2, the $\mathrm{F}$ test is not conclusive, and therefore, means were compared to detect relevant differences.

Data of all parameters were also submitted to canonical discriminant analysis with the aim of identifying parameters that would allow discriminating differences between feed and water electrolyte balance for quails reared at different temperatures. Both analysis of variance, using the GLM procedure, and canonical discriminant analysis, using the CANDISC procedure, were carried out by SAS 9.0 (2002) software package and $5 \%$ significance levels was applied.

\section{RESULTS}

\section{Experiment 1: Feed electrolyte balance}

Environmental temperature influenced $(p<0.01)$ the evaluated parameters (Tables 2 and 3), except for gizzard relative weight, as shown in Table 3.
Table 2 - Effect of feed electrolyte balance (EB, $\mathrm{mEq} / \mathrm{kg}$ ) and environmental temperature $\left(\mathrm{T},{ }^{\circ} \mathrm{C}\right)$ on the performance of European at 37 days of age.

\begin{tabular}{lcccc}
\hline EB & WG $(\mathrm{g})$ & $\mathrm{Fl}(\mathrm{g})$ & $\mathrm{FCR}(\mathrm{g} / \mathrm{g})$ & ${ }^{(1)} \mathrm{WI}(\mathrm{mL})$ \\
\hline 0 & 95.0 & 353.7 & 3.79 & 1067.1 \\
\hline 120 & 96.3 & 369.6 & 3.87 & 999.2 \\
\hline 240 & 96.0 & 367.4 & 4.1 & 866.7 \\
\hline 360 & 93.1 & 348.3 & 3.65 & 1140.3 \\
\hline $\mathrm{T}$ & $\mathrm{WG}(\mathrm{g})$ & $\mathrm{Fl}(\mathrm{g})$ & $\mathrm{FCR}(\mathrm{g} / \mathrm{g})$ & $\mathrm{WI}(\mathrm{mL})$ \\
\hline $34^{\circ} \mathrm{C}$ & $88.04 \mathrm{~b}$ & $305.3 \mathrm{~b}$ & $3.48 \mathrm{~b}$ & $1315.7 \mathrm{a}$ \\
\hline $25^{\circ} \mathrm{C}$ & $100.4 \mathrm{a}$ & $414.2 \mathrm{a}$ & $4.22 \mathrm{a}$ & $720.94 \mathrm{~b}$ \\
\hline ANOVA & $\mathrm{WG}(\mathrm{g})$ & $\mathrm{FI}(\mathrm{g})$ & $\mathrm{FCR}(\mathrm{g} / \mathrm{g})$ & $\mathrm{WI}(\mathrm{mL})$ \\
\hline EB & $\mathrm{ns}$ & $\mathrm{ns}$ & $\mathrm{ns}$ & $*$ \\
\hline $\mathrm{T}$ & $*$ & $*$ & $*$ & $*$ \\
\hline EBxT & $\mathrm{ns}$ & $\mathrm{ns}$ & $\mathrm{ns}$ & $\mathrm{ns}$ \\
\hline $\mathrm{CV} \%$ & 13.4 & 7.6 & 16.6 & 15.5 \\
\hline
\end{tabular}

(1) $y=1090.6-2.0618 x+0.0059 x^{2} ; R^{2}=0.73$. Means followed by the same letter are not significantly different by the $\mathrm{F}$ test at $5 \%$ probability level; ${ }^{*} \mathrm{p}<0.05$; ns = not significant; $W G=$ weight gain; $F I=$ feed intake; $F C R=$ feed conversion ratio; $W I=$ water intake.

Table 3 - Effect of feed electrolyte balance (EB, $\mathrm{mEq} / \mathrm{kg}$ ) and environmental temperature $\left(\mathrm{T},{ }^{\circ} \mathrm{C}\right)$ on carcass yield and organ relative weight of European quails at 37 days of age.

\begin{tabular}{llllll}
\hline EB & CY (\%) & G (\%) & H (\%) & ${ }^{(1)} \mathrm{lL}(\mathrm{cm})$ & $\mathrm{IW}(\%)$ \\
\hline 0 & 76.6 & 2.67 & 1.12 & 56.8 & 4.89 \\
\hline 120 & 75.7 & 2.63 & 1.15 & 58.2 & 5.31 \\
\hline 240 & 75.0 & 2.79 & 1.09 & 63.7 & 5.32 \\
\hline 360 & 75.3 & 2.78 & 1.06 & 59.9 & 4.74 \\
\hline $\mathrm{T}$ & $\mathrm{CY}(\%)$ & $\mathrm{G}(\%)$ & $\mathrm{H}(\%)$ & $\mathrm{IL}(\mathrm{cm})$ & $\mathrm{IW}(\%)$ \\
\hline 34 & $78.3 \mathrm{~b}$ & 2.70 & $0.89 \mathrm{a}$ & $55.85 \mathrm{~b}$ & 4.26 \\
\hline 25 & $73.0 \mathrm{a}$ & 2.73 & $1.32 \mathrm{~b}$ & $63.63^{\mathrm{a}}$ & 5.87 \\
\hline ANOVA & $\mathrm{CY}(\%)$ & $\mathrm{G}(\%)$ & $\mathrm{H}(\%)$ & $\mathrm{IL}(\mathrm{cm})$ & $\mathrm{IW}(\%)$ \\
\hline EB & $\mathrm{ns}$ & $\mathrm{ns}$ & $\mathrm{ns}$ & $* *$ & $\mathrm{~ns}$ \\
\hline T & $* *$ & $\mathrm{~ns}$ & $* *$ & $* *$ & $* *$ \\
\hline EBxT & $\mathrm{ns}$ & $\mathrm{ns}$ & $\mathrm{ns}$ & $\mathrm{ns}$ & $\mathrm{ns}$ \\
\hline CV \% & 4.3 & 9.3 & 12.2 & 7.79 & 14.81
\end{tabular}

(1) $y=56.13+0.0448 x-9 E-05 x^{2} ; R^{2}=0.66$. Means followed by the same letter are not significantly different by the $F$ test at $5 \%$ probability level; ${ }^{*} \mathrm{p}<0.05$; ns $=$ not significant; $\mathrm{CY}=$ carcass yield; $\mathrm{G}=$ gizzard relative weight; $\mathrm{H}=$ heart relative weight; $\mathrm{IL}=$ intestinal length; $\mathrm{IW}=$ intestine relative weight.

The feed intake of quails reared at $34{ }^{\circ} \mathrm{C}$ was, on average, $29.9 \%$ lower than those reared at $25^{\circ} \mathrm{C}$. This feed intake reduction explains the lower weight gain of the quails reared under hot temperature. Feed conversion ratio was also influenced by environmental temperature, and the best values were obtained in quails reared at $34^{\circ} \mathrm{C}$. Relative to carcass traits, quails reared in the hot environment presented higher 
carcass yield (Table 3) due to their lower viscera development. Intestinal length increased up with $\mathrm{NaHCO}_{3}$ supplementation up to dietary $246 \mathrm{mEq} / \mathrm{kg}$ EB and then decreased. Mortality was not influenced by the treatments.

Table 4 - Deployment of the degrees of freedom and comparison of water intake means $(\mathrm{Wl}, \mathrm{mL})$ of European quails at 37 days of age.

\begin{tabular}{lcc}
\hline EB & \multicolumn{2}{c}{ WI } \\
\cline { 2 - 3 } & $34{ }^{\circ} \mathrm{C}$ & $25^{\circ} \mathrm{C}$ \\
\hline 0 & $1369.4 \mathrm{aA}$ & $764.88 \mathrm{bAB}$ \\
\hline 120 & $1323.6 \mathrm{aA}$ & $674.78 \mathrm{bAB}$ \\
\hline 240 & $1141.3 \mathrm{aA}$ & $592.02 \mathrm{bB}$ \\
\hline 360 & $1428.5 \mathrm{aA}$ & $852.07 \mathrm{bA}$ \\
\hline
\end{tabular}

$A, B=$ Means followed by the same upper-case letters in the same column are not significantly different by the SNK test $(p \leq 0.05) . a, b=$ Means followed by the same lower-case letter in the same row are not significantly different by the $F$ test $(p \leq 0.05)$.

Electrolyte balance affected water intake only of the quails reared at $25^{\circ} \mathrm{C}$.

\section{Experiment 2: Water electrolyte balance}

Performance and organ relative weight results are shown in Tables 5 and 6 . Weight gain and liver relative weight were influenced by the interaction between $\mathrm{EB}$ and environmental temperature. Water intake and heart relative weight were affected by EB. Environmental temperature significantly influenced all evaluated parameters.

Table 5 - Effect of drinking water electrolyte balance (EB, $\mathrm{mEq} / \mathrm{kg}$ ) and environmental temperature $\left(\mathrm{T},{ }^{\circ} \mathrm{C}\right)$ on the performance of European at 37 days of age.

\begin{tabular}{lcccc}
\hline EB & WG $(\mathrm{g})$ & $\mathrm{Fl}(\mathrm{g})$ & $\mathrm{FCR}(\mathrm{g} / \mathrm{g})$ & ${ }^{(1)} \mathrm{Wl}(\mathrm{mL})$ \\
\hline 0 & 93.08 & 353.71 & 3.79 & 1067.13 \\
\hline 30 & 85.12 & 351.29 & 4.17 & 991.25 \\
\hline 60 & 85.68 & 346.88 & 4.12 & 936.70 \\
\hline 90 & 90.31 & 377.73 & 4.24 & 982.83 \\
\hline 120 & 91.20 & 364.53 & 3.90 & 1173.48 \\
\hline $\mathrm{T}$ & $\mathrm{WG}(\mathrm{g})$ & $\mathrm{Fl}(\mathrm{g})$ & $\mathrm{FCR}(\mathrm{g} / \mathrm{g})$ & $\mathrm{Wl}(\mathrm{mL})$ \\
\hline 34.0 & $76.49 \mathrm{~b}$ & $296.59 \mathrm{~b}$ & 3.85 & $1291.50 \mathrm{a}$ \\
\hline 25.0 & $101.67 \mathrm{a}$ & $421.07 \mathrm{a}$ & 4.18 & $769.06 \mathrm{~b}$ \\
\hline ANOVA & WG (g) & $\mathrm{Fl}(\mathrm{g})$ & $\mathrm{FCR}(\mathrm{g} / \mathrm{g})$ & $\mathrm{Wl}(\mathrm{mL})$ \\
\hline EB & $\mathrm{ns}$ & $\mathrm{ns}$ & $\mathrm{ns}$ & $*$ \\
\hline $\mathrm{T}$ & $*$ & $*$ & $*$ & $*$ \\
\hline EBxT & $*$ & $\mathrm{~ns}$ & $\mathrm{~ns}$ & $\mathrm{~ns}$ \\
\hline CV $\%$ & 11.223 & 11.135 & 14.399 & 13.831
\end{tabular}

(1) $y=1079.9-5.3542 x+0.0503 x^{2} ; R^{2}=0.96$. Means followed by the same letter are not significantly different by the $\mathrm{F}$ test at $5 \%$ probability level; ${ }^{*} \mathrm{p}<0.05 ; \mathrm{ns}=$ not significant. WG = weight gain; $F I=$ feed intake; $F C R=$ feed conversion ratio; $W I=$ water intake.
Table 6 - Effect of drinking water electrolyte balance (EB, $\mathrm{mEq} / \mathrm{kg}$ ) and environmental temperature $\left(\mathrm{T},{ }^{\circ} \mathrm{C}\right)$ on organ relative weight of European at 37 days of age.

\begin{tabular}{|c|c|c|c|c|c|c|}
\hline EB & $\mathrm{FW}(\mathrm{g})$ & CY (\%) & G (\%) & $H(\%)$ & (1) LW (\%) & $\mathrm{IL}(\mathrm{cm})$ \\
\hline 0 & 219.3 & 76.4 & 2.29 & 1.04 & 2.94 & 56.8 \\
\hline 30 & 213.0 & 73.4 & 2.29 & 1.02 & 3.24 & 64.2 \\
\hline 60 & 214.6 & 75.0 & 2.57 & 1.08 & 3.17 & 63.0 \\
\hline 90 & 217.9 & 74.8 & 2.55 & 1.18 & 3.32 & 61.6 \\
\hline 120 & 221.5 & 73.2 & 2.37 & 1.09 & 3.17 & 61.0 \\
\hline T & $\mathrm{FW}(\mathrm{g})$ & CY (\%) & G (\%) & $H(\%)$ & LW (\%) & $\mathrm{IL}(\mathrm{cm})$ \\
\hline 34.0 & $203.96 b$ & $77.29 a$ & $2.75 a$ & $1.17 a$ & $3.35 a$ & $57.16 b$ \\
\hline 25.0 & $230.57 a$ & $71.86 \mathrm{~b}$ & $2.08 b$ & $1.00 \mathrm{~b}$ & $2.99 b$ & $65.44 a$ \\
\hline ANOVA & $\mathrm{FW}(\mathrm{g})$ & CY (\%) & $\mathrm{G}(\%)$ & $\mathrm{H}(\%)$ & LW (\%) & $\mathrm{IL}(\mathrm{cm})$ \\
\hline EB & ns & ns & ns & * & ns & ns \\
\hline$T$ & * & * & * & * & * & * \\
\hline $\mathrm{Be}^{*} \mathrm{~T}$ & ns & ns & ns & ns & * & ns \\
\hline CV \% & 5.0 & 3.9 & 12.1 & 10.4 & 14.5 & 11.6 \\
\hline
\end{tabular}

(1) $y=2.9629+0.0083 x-5 E-05 x^{2} ; R^{2}=0.77$. Means followed by the same letter are not significantly different by the $\mathrm{F}$ test at $5 \%$ probability level; ${ }^{*} \mathrm{p}<0.05$; ns $=$ not significant; $F W=$ final weight; $\mathrm{CY}=$ carcass yield; $\mathrm{G}=$ gizzard relative weight; $\mathrm{H}=$ heart relative weight; $\mathrm{LW}=$ liver relative weight; $\mathrm{IL}=$ intestinal length

Weight gain of the birds fed $\mathrm{NaHCO}_{3}$ via drinking water was affected by the interaction of the evaluated factors (BE X T), as shown in Table 7. According to the deployment of the interaction (BE $\times \mathrm{T}$ ) for weight gain, means indicate that temperature had a greater effect than $B E$, as after the deployment, no effect of $B E$ on weight gain was found.

Water intake of birds reared in the hot environment was significantly influenced by EB. Water intake was higher in birds fed 60 and $90 \mathrm{mEq} / \mathrm{L}$, but similar in birds fed diets with EB values of 0,30 , and $120 \mathrm{mEq} / \mathrm{L}$.

Heart relative weight was quadratically affected by drinking water supplementation with $\mathrm{NaHCO}_{3}$ up to a maximum EB value of $112.5 \mathrm{mEq} / \mathrm{L}$ (Table 7 ).

Mortality was not influenced by the treatments.

The first two canonical parameters explained $94 \%$ of total variation, but none was significant at probability levels higher than $78 \%$.

\section{DISCUSSION}

High environmental temperature reduces feed intake and weight gain. Birds reduce their feed intake in an attempt to decreased heat increment produced by nutrient digestion and metabolism (Lesson \& Summers, 2001). In the present experiment, quails reared at $34^{\circ} \mathrm{C}$ consumed $35.65 \%$ less feed than those reared at $25^{\circ} \mathrm{C}$ in both experiments. The observed weight reduction of the quails maintained at $34^{\circ} \mathrm{C}$ is typical of 
Table 7 - Deployment of degrees of freedom and comparison of weight gain (WG, g), water intake (WI, $\mathrm{mL})$, heart relative weight $(\mathrm{H}, \%)$, and liver relative weight $(\mathrm{L}, \%)$ of European quails at 37 days of age.

\begin{tabular}{lcccccccc}
\hline EB & \multicolumn{7}{c}{$\mathrm{WG}$} & \multicolumn{3}{c}{${ }^{(1)} \mathrm{Wl}$} & & & \\
& $34{ }^{\circ} \mathrm{C}$ & $25{ }^{\circ} \mathrm{C}$ & $34{ }^{\circ} \mathrm{C}$ & $25{ }^{\circ} \mathrm{C}$ & $34{ }^{\circ} \mathrm{C}$ & $25{ }^{\circ} \mathrm{C}$ & $34{ }^{\circ} \mathrm{C}$ & $25{ }^{\circ} \mathrm{C}$ \\
\hline 0 & $86.7 \mathrm{aA}$ & $99.5 \mathrm{aA}$ & $1369.4 \mathrm{abA}$ & $764.9 \mathrm{aB}$ & $1.15 \mathrm{aA}$ & $0.93 \mathrm{bB}$ & $3.03 \mathrm{aA}$ & $2.86 \mathrm{aA}$ \\
\hline 30 & $76.3 \mathrm{aB}$ & $93.9 \mathrm{aA}$ & $1255.8 \mathrm{abA}$ & $726.7 \mathrm{aB}$ & $1.10 \mathrm{aA}$ & $0.94 \mathrm{bB}$ & $3.09 \mathrm{aA}$ & $3.39 \mathrm{aA}$ \\
\hline 60 & $74.4 \mathrm{aB}$ & $96.9 \mathrm{aA}$ & $1191.8 \mathrm{bA}$ & $681.7 \mathrm{aB}$ & $1.16 \mathrm{aA}$ & $1.01 \mathrm{bB}$ & $3.32 \mathrm{aA}$ & $3.03 \mathrm{aA}$ \\
\hline 90 & $70.2 \mathrm{aB}$ & $110.4 \mathrm{aA}$ & $1186.3 \mathrm{bA}$ & $779.4 \mathrm{aB}$ & $1.19 \mathrm{aA}$ & $1.17 \mathrm{aA}$ & $3.70 \mathrm{aA}$ & $2.93 \mathrm{aB}$ \\
\hline 120 & $74.8 \mathrm{aB}$ & $107.6 \mathrm{aA}$ & $1454.3 \mathrm{aA}$ & $892.6 \mathrm{aB}$ & $1.24 \mathrm{aA}$ & $0.95 \mathrm{bB}$ & $3.59 \mathrm{aA}$ & $2.74 \mathrm{aB}$ \\
\hline Effect & $\mathrm{ns}$ & $\mathrm{ns}$ & $\mathrm{Q}$ & $\mathrm{ns}$ & $\mathrm{Q}$ & $\mathrm{ns}$ & $\mathrm{L}$ & $\mathrm{n}$ \\
\hline
\end{tabular}

$y=1388.8-7.4923 x+0.0652 x^{2} ; R^{2}=0.9 . y=1.1383-0.0007 x+1 E-05 x^{2} ; R^{2}=0.88$. (3) $y=3.0007+0.0058 x ; R^{2}=0.86$. A,B $=$ Means followed by the same upper-case letters in the same row are not significantly different by the SNK test $(p \leq 0.05)$. $a, b=$ Means followed by the same lower-case letter in the same column are not significantly different by the F test $(p \leq 0.05)$

birds submitted to heat stress due to increase in energy requirements for thermoregulation and reduced feed intake, resulting in better feed conversion ratio $(p<$ $0.01)$. In addition, the reduced feed intake determined $26 \%$ lower protein intake (70 g vs. 95 g crude protein), affecting intestinal and liver weight of the heat-stressed quails. As observed in both experiments, organ relative weights of birds reared at higher environmental temperatures tend to be indirectly affected by feed and water intake or directly by compensatory metabolic changes. Therefore, organs may present different development patterns according to their digestive or homeostasis purpose: excretion (kidneys), circulation, and respiration. This issue was not explored in none of the articles mentioned in the present study.

Heart relative weight presented a different behavior between experiments under the same environmental condition because it was influenced by $\mathrm{NaHCO}_{3}$ supplementation in the drinking water in experiment 2 (Tables 3 and 6). Although hypertension, heart wall, and heart index were not measured, the results suggests that sodium levels affect heart relative weight of quails maintained at high temperatures. Bold et al. (1981), quoted by Maack et al. (1985), discovered that the heart has an important endocrine role in sodium excretion through the action of a hormone ANP (atrial natriuretic peptide) that is also one of the main endogenous substances involved in heart hypertrophy (Bubikat et al., 2005). Indeed, heart relative weight was reduced under the influence of high temperature in experiment 1 , but in experiment 2 , EB increased it $(p<$ 0.05 ), i.e., heart relative weight was affected by sodium levels in the drinking water, which ranged between 68 and $275 \mathrm{mg} / \mathrm{L}$. Sodium ingestion levels may cause heart muscle changes in relatively short times, such as hypertrophy, as demonstrated in experiments with rats (Selye \& Bajusz, 1959; Lindpaintner \& Sen, 1985). This was also observed by Silva et al. (2006) in white and brown layer pullets, who, in addition of heavier hearts, also found heavier liver, spleen, and cloacal bursa when dietary sodium levels increased.

The highest water intakes were determined at the highest salt supplementation levels in the basal feed $\left(1.18 \% \mathrm{NH}_{4} \mathrm{Cl}\right.$ and $\left.1.342 \% \mathrm{NaHCO}_{3}\right)$, independently of feed electrolyte balance. These compounds have other effects than increasing water intake of poultry submitted to heat stress. Teeter et al. (1985) showed that, under heat stress, the administration both of sodium and of acidifiers as ammonium chloride reduce the severity of respiratory alkalosis by increasing blood $\mathrm{pH}$ when broilers were fed $0.5 \% \mathrm{NaHCO}_{3}$ in the diet. However, no other published data that confirmed those results were found.

Most of the mentioned studies do not show any evidence of the effect of sodium bicarbonate or ammonium chloride on the blood $\mathrm{pH}$ of heat-stressed poultry. $\mathrm{HCO}_{3}$ is a metabolic product that changes acid-base balance.

Water intake is a parameter that monitors the efficiency of salt supplementation, and the addition of sodium sources to the drinking water or feed increases voluntary water intake in poultry compared with other electrolytes, as shown since the first experiments on this subject (Ross, 1979; Teeter \& Smith, 1986; Mushtaq et al., 2005). Therefore, when water intake is related with sodium intake in experiment 1 , where feed sodium levels ranged between 0.109 and $0.433 \%$ (null EB and $360 \mathrm{mEq} / \mathrm{kg}$ ), the highest Na level promoted the highest water intake of the quails in the heat-stress environment (Table 4). This also happened in experiment 2, with total sodium levels of 0.178 $0.384 \%$. In studies with pre-starter broilers, Maiorka et al. (2004) reported that $0.45 \%$ dietary sodium resulted in the highest water intake compared with $0.10,0.22$, and $0.34 \%$. When sodium bicarbonate was diluted in water (experiment 2), the basal diet contributed with $0.109 \%$ sodium, and sodium levels 
Barbosa Lima R, Silva JHV da, Givisiez PEN, Martins TDD, Saraiva EP, Costa FGP, Macari M

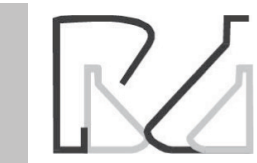

Influence of Environmental Temperature and Electrolyte Balance on the Performance of Quails (Coturnix Coturnix Coturnix) in the electrolyte solutions ranged between 0.069 and $0.275 \%$. Therefore, although the highest level of total sodium in experiment 2 was lower than in experiment 1, water intake was similar. These results indicate that sodium supplementation via drinking water was more efficient to increase water intake than via feed. This is consistent with the finding of Ross (1979), who compared these two sodium supplementation routes (the basal diet contained $0.095 \%$ sodium), and concluded that sodium utilization was more efficient when it was added to the drinking water.

The supply of saline solutions to stimulate nutrient absorption (co-transport) is a well-known practice (Jeukendrup et al., 2009). In experiment 1, as previously mentioned, EB levels were obtained by the inclusion of sodium, as sodium bicarbonate, in the feed, which may explain the significant effect $(y=56.13+0.0448 x$ $-9 \mathrm{E}-05 \mathrm{x}^{2} ; \mathrm{R}^{2}=0.66$ ) of EB on intestinal length (Table 3 ), possibly due to the increase in sodium, glucose, amino acid, and water absorption. González et al. (1998) verified the presence of specific binding sites of the ANP hormone in rats; these sites act as mediators of sodium, glucose, and water absorption. These results were confirmed in subsequent studies (Nakamura et al., 2003), and mentioned in a recent paper on this subject (Yoshikawa et al., 2011).

The use of chlorides $\left(\mathrm{KCl}, \mathrm{NH}_{4} \mathrm{Cl}\right)$ to induce water intake in heat-stressed poultry has been studied (Souza et al., 2005; Sousa et al., 2009), but it seems that water intake does not depend only on supplementation, but it is also influenced by diet composition, bird sex, and stress magnitude and duration. In general, increasing the intake of sodium as $\mathrm{NaHCO}_{3}$ and $\mathrm{NaCl}$ activates the thirst control system to maintain body water balance.

Based on the mentioned articles and in the results of the present study, performance under heat stress conditions is extremely variable (Ahmad et al., 2005, Mushtaq et al., 2005 Mushtaq et al., 2007, Ahmad et al., 2008). In addition to experimental errors inherent to animals and diets, toxicity should be considered (Teeter \& Smith, 1986; Souza et al., 2005), as different sodium bicarbonate or ammonium chloride levels may change water and feed intake of individual birds. Ammonium chloride is an acidifier, and its chronic ingestion may have caused metabolic changes, which may have been also indirectly affected by changes in circulating calcium levels (Dacke et al., 1973) and by $\mathrm{NaHCO}_{3}$ ingestion. Teeter \& Smith (1986) demonstrated that $\mathrm{NH}_{4} \mathrm{Cl}$ efficiently overcomes heatstress effects, but levels of $0.5 \%$ or higher are toxic, whereas Souza et al. (2005) suggest a maximum level of $0.4 \% \mathrm{NH}_{4} \mathrm{Cl}$. Therefore, the difference in ammonium chloride levels in the experimental diets (exp. 1) may have influenced quail responses among treatments, considering that, in order to obtain the expected EB values, different levels of this compound were added to the diets. In addition, as well as with sodium bicarbonate, the effect of the addition of chlorine may change with its source, because bicarbonate, ammonium ion, and its oxidized form (ammonia) are involved in the acid-base balance (Verlander 2004a, 2004b). Scientific studies on the use of salts as feeding practice to reduce the effect of heat stress generally aim only at increasing water intake (Smith, 1994), but this does not seem to be the only effects observed when sodium bicarbonate and ammonium chloride are used.

It is difficult to compare the effects and salt supplementation levels in the feed and drinking water among studies. In addition to different rearing phases and different diet compositions, salt sources may also be different. Even when equal EB values are used (in $\mathrm{mEq} / \mathrm{kg}$ feed), different sources $\left(\mathrm{KCl}, \mathrm{NaCl}, \mathrm{NaHCO}_{3}\right)$ determine different $\mathrm{K}^{+}, \mathrm{Na}^{+}$, or $\mathrm{Cl}^{-}$concentrations. Therefore, a same EB value may have different effects, as shown by the results of Teeter et al. (1986) and Ahmad et al. (2005). Moreover, sodium or potassium chloride supply a strong anion and a strong cation, and the $(\mathrm{Na}+\mathrm{K}) / \mathrm{Cl}$ ratio is not changed, even at high concentrations.

The results showed that temperature was not the only detrimental agent or stressor that affected quail growth. Changes in dietary and environmental patterns may have also influenced their metabolism. The observed liver changes illustrate this hypothesis. In experiment 2, liver relative weight increased $(p<$ 0.005 ) as sodium bicarbonate supplementation levels increased (Table 7). However, no direct relationship between electrolyte balance and liver relative weight was found in literature. The lowest weight gain $(70.2 \mathrm{~g}$, Table 7), obtained in the hot-temperature environment, was not affected by electrolyte balance, as most of the other parameters, but EB of $120 \mathrm{mEg} / \mathrm{kg}$ feed and 30 $\mathrm{mEq} / \mathrm{L}$ water is recommended to increase water intake of growing European quails.

\section{CONCLUSIONS}

Electrolyte balance values of $120 \mathrm{mEq} / \mathrm{kg}$ of feed and of $30 \mathrm{mEq} / \mathrm{L}$ of drinking water are recommended to increase water intake of growing European quails reared at $34^{\circ} \mathrm{C}$. 


\section{ACKNOWLEDGEMENTS}

This research was supported by Nacional Research Council (CNPq/Brazil). This paper is technical contribution number 577873, CNPq.

\section{REFERENCES}

Ahmad T, Khalil T, Mushtag T, Mirza MA, Nadeem A, Barabar ME, Ahmad G. Effect of potassium chloride supplementation in drinking water on broiler performance under heat stress conditions. Poultry Science 2008;87:1276-1280

Ahmad T, Sarwar M, Nisa MU, Haq AU, Hasan ZU. Influence of varying sources of dietary electrolytes on the performance of broilers reared in a high temperature environment. Animal Feed Science and Technology 2005;120:277-298.

Bubikat A, León J. De Windt, Bernd Zetsche, Larissa Fabritz, Heidrun Sickler, Dominik Eckardt, Axel Gödecke, Hideo A. Baba, and Michaela Kuhn. Local atrial natriuretic peptide signaling prevents hypertensive cardiac hypertrophy in endothelial nitric-oxide synthase-deficient mice. The Journal Biological Chemistry 2005;280(22):21594 -21599.

Borgatti LMO, Albuquerque R, Meister NC, Souza LWO, Lima FR, Trindade Neto MA. Performance of broilers fed diets with different dietary electrolyte balance under summer conditions. Revista Brasileira de Ciência Avícola 2004;6(3):153-157.

Dacke CG, Musacchia XJ, Volkert WA, Kenny AD. Cyclical fluctuations in the levels of blood calcium, $\mathrm{pH}$ and $\mathrm{pCO} 2$ in Japanese quail. Comparative Biochemistry and Physiology Part A 1973; 44(4):1267-1275.

Jeukendrup AE, Currell K, Clarke J, Cole J, Blannin AK. Effect of beverage glucose and sodium content on fluid delivery . Nutrition \& Metabolism 2009:6:9-15

Gonzalez BLV, Vidal NA, Prieto R, Tur JA. Effect of atrial natriuretic peptide on $-\alpha$ - Methyl-D-glucoside intestinal active uptake in rats. Peptides 1998; 19:1249-1253

Junqueira OM, Camargo Filho B, Araújo LF, Araújo CSS, Sakomura NK. Efeitos das fontes e níveis de sódio, cloro e potássio e da relação ( $\mathrm{Na}+$ $\mathrm{K}) / \mathrm{Cl}$, sobre o desempenho e características do plasma sangüíneo de poedeiras comerciais. Revista Brasileira de Zootecinia 2000;29(4):11101116

Lesson S, Summers JD. Scott's Nutrition of the Chickens. 4. ed. Ontario: University books, 2001. 591p.

Lindpaintner K, Sen S. Role of sodium in hypertensive cardiac hypertrophy. Circulation Research 1985;57:610-617.

Maack T, Camargo MJ, Kleinert HD, Laragh JH, Atlas SA. Atrial natriuretic factor: structure and functional properties. Kidney International $1985 ; 27: 607-615$.

Maiorka A, Magro N, Bartels HAS, Kessler AM, Penz Jr AM. Different sodium levels and electrolyte balances in pre-starter diets for broilers. Revista Brasileira de Ciência Avícola 2004;6(3):143-146.

Mcllvaine J. O Biogeography of California Quail (Callipepla californica). Available from: http://bss.sfsu.edu/holzman/courses/fall00projects/ quail.html

Mongin P. Recent advances in dietary ânion-cátion balance: applications in poultry. Proceedings of the Nutrition Society 1981;40(1):285-294.

Mushtaq T, Mirza AM, Athar M, Hooge DM., Ahmad T, Ahmad G, Mushtaq $\mathrm{MMH}$, Noreen U. Dietary sodium and chloride for twenty-nine-to forty- two-day-old broiler chickens at constant electrolyte balance under subtropical summer conditions. Journal Applied of Poultry Research 2007:16:161-170.

Mushtaq T, Sarwar, M, Nawaz, H, Mirza, MA, Ahmad, T. Effect and interactions of dietary sodium and chloride on broiler starter performance (hatching to twenty-eight days of age) under subtropical summer conditions. Poultry Science 2005; 84; 1716-1722.

Nakamura K, Takayama K, Nagai T, Maitani Y. Regional intestinal absorption of FITC-dextran 4.400 with nanoparticles based on $\beta$-sitosterol $\beta$-Dglucoside in rats. Journal of Pharmaceutical Sciences 2003;92(2/1):311 318

Ross E. The effect of water sodium on the chick requirement for dietary sodium. Poultry Science 1979;58:626-630

Sampaio IBM. Estatística aplicada à experimentação animal. Belo Horizonte: Fundação de Ensino e Pesquisa em Medicina Veterinária e Zootecnia; 1998. $221 \mathrm{p}$.

Selye H, Bajusz E. Effect of various electrolytes upon cardiac and skeleta musculature. British Journal of Pharmacology 1959;14: 83-86.

Silva JHV, Costa FGP. Tabela para codornas japonesas e européias. $2^{\mathrm{a}}$ ed. Ed. FUNEP, Jaboticabal, SP, 110p, 2009

Silva JHV, Ribeiro MLG, Jordão Filho J, Silva EL. O sódio afeta o crescimento de órgãos dos sistemas circulatório, digestivo e imune de frangas. Revista AveWorld 2006:23:8-9.

Sousa Junior FN, Figueirêdo AV, Lopes JB, Ramos LSN. Bicarbonato de sódio e cloreto de amônio em rações para frangos de corte sob condições naturais de estresse térmico. Revista Científica de Produção Anima 2009;11(1): 23-33.

Souza BB, Bertechini AG, Teixeira AS, Lima JAF, Conte AJ. Efeito do nível energético e da suplementação com cloretos de potássio e de amônia na dieta sobre as respostas fisiológicas e o desempenho de frangos de corte no verão. Ciência e Agrotecnologia, Lavras 2005;29(1):185-192.

Smith MO. Effect of electrolytes and lighting regimen on growth of heat distressed broilers. Poultry Science 1994. 73 (2): 350-353.

Statistical Analysis System. User's guide. Cary: SAS Institute; 2002. 525p.

Teeter RG, Smith M. High chronic ambient temperature stress effects on broiler acid-base balance and their response to supplemental ammonium chloride potassium chloride, and potassium carbonate. Poultry Science 1986; 65(9):1777-1781

Teeter RG, Smith MO, Owens FN, Arp SC, Sangiah S, Breazile JE. Chronic heat stress and respiratory alkalosis: occurrence and treatment in broiler chicks. Poultry Science 1985; 64(6):1060-4

Verlander JW. Equilíbrio ácido-básico. In: Cunningham JG. Tratado de fisiologia veterinária. Rio de Janeiro: Guanabara - Koogan; 2004b. p 471-477.

Verlander JW, Reabsorção de solutos. In: Cunningham JG. Tratado de fisiologia veterinária. Rio de Janeiro: Guanabara - Koogan, 2004a. p.452-462.

Wilk B, Rivera-Brown AM, Bar-Or O. Voluntary drinking and hydration in non-acclimatized girls exercising in the heat. European Journal of Applied Physiology 2007; 101(6):727-34

Yoshikawa $\mathrm{T}$, Inoue $\mathrm{R}$, Matsumoto $\mathrm{M}$. Yajima $\mathrm{T}$, Ushida $\mathrm{K}$, Iwanaga $\mathrm{T}$. Comparative expression of hexose transporters (SGLT1, GLUT1, GLUT2 and GLUT5) throughout the mouse gastrointestinal tract. Histochemistry and Cell Biology 2011;135(2):183-194. 
